\title{
CLASSROOM ACTIVITIES FOR TEACHING SPEAKING: VOICES OF INDONESIAN EFL LEARNERS
}

\author{
Arif Nugroho $^{1}$, Novrika Nartiningrum ${ }^{2}$ \\ ${ }^{12}$ English Education Department, Faculty of Adab and Language, IAIN Surakarta, Indonesia \\ Language Center, University of Muhammadiyah Malang, Indonesia \\ Corresponding Email: arifnugroho.iainsurakarta@gmail.com
}

Received: $4^{\text {th }}$ of April 2020, Accepted: $3^{\text {rd }}$ of May 2020, Published: 22th of June 2020

\begin{abstract}
Among the four English skills, oral communication becomes crucial for undergraduate students to be more competitive in the work-places. In a foreign language teaching, designing appropriate classroom activities is a prerequisite for the success of a language learning. Therefore, this study sheds some light on $92 \mathrm{EFL}$ learners' perceptions and insights of classroom activities for teaching speaking. Drawing on the data obtained from questionnaire and focus group discussion (FGD), the findings illustrated that the students held moderately positive perceptions toward the speaking activities in their classroom. In addition, the results of FGD revealed some insights from the students with regard to the ideal classroom activities for teaching speaking. The findings of this study provide insights for EFL teachers in designing appropriate classroom activities to achieve the success of teaching speaking.
\end{abstract}

Keywords: teaching speaking, classroom activities, students' perception

\begin{abstract}
Abstrak
Di antara empat keterampilan bahasa Inggris, komunikasi lisan menjadi sangat penting bagi mahasiswa sarjana untuk mampu bersaing di dunia kerja. Dalam pengajaran bahasa asing, merancang kegiatan kelas yang sesuai adalah prasyarat mutlak untuk keberhasilan pembelajarn bahasa. Oleh karena itu, penelitian ini menjelaskan persepsi dan masukan dari 92 mahasiswa jurusan Pendidikan Bahasa Inggris tentang kegiatan kelas untuk pengajaran berbicara. Kesimpulan dari data yang diperoleh dari kuesioner, dan diskusi kelompok terfokus (FGD) menggambarkan bahwa mahasiswa memiliki persepsi yang cukup positif terhadap kegiatan berbicara di kelas mereka. Selain itu, hasil FGD mengungkapkan beberapa masukan dari mahasiswa sehubungan dengan kegiatan kelas yang ideal untuk pengajaran berbicara. Temuan dalam penelitian ini memberikan wawasan untuk dosen Bahasa Inggris dalam merancang kegiatan kelas yang tepat untuk mencapai keberhasilan pengajaran berbicara.
\end{abstract}

Kata kunci: pengajaran berbicara, kegiatan kelas, persepsi mahasiswa

Copyright () 2020 Arif Nugroho, Novrika Nartiningrum

\section{INTRODUCTION}

When undergraduate students are asked which English skill, among the four, is the most difficult, the researchers do believe that most of them will answer speaking. The workingenvironment where most companies and institutions operates in nowadays is more competitive. It requires them to provide high standards when hiring employees especially positions which involve English communication skill. This is in line with the statement of Zedeck et al. (2000) which stated that oral communication skill is the main priority among other skills in the process of recruiting the employees. 
Despite the fact that Indonesia is the largest labor contributor in ASEAN, the English competence level of Indonesian labors is still below the expectation (Keliat, 2013). According to Education First's English Proficiency Index (EPI), which ranked countries based on their skills in English language, Indonesia was ranked $32^{\text {nd }}$ place out of 72 countries surveyed in 2016. This surely has an effect on the process of hiring employees. A study done by Renandya et al. (2018) mentioned that the majority of English teachers in Indonesia probably fall in the lower intermediate range, probably in B1-B2 levels on CEFR scale. Renandya et al. (2018) also said that senior teachers and teacher educators that they have worked with often share their observations with them. They said that many Indonesian English teachers are not very fluent and lack not so confident in using the language inside and outside of the classroom.

Abrar et al. (2018) documented Indonesian EFL student teachers' experiences in speaking English. They found some challenges faced by participants in speaking English. The languagerelated barriers (vocabulary, pronunciation, grammar and fluency) became the main obstacle for the participants when speaking English. These problems hinder the participants from getting involved in English conversations. Thus, language classroom needs appropriate and interesting learning activities to foster students' motivation in maximizing the available learning sources (Darmadi et al., 2019).

Another study done by Noprival (2017) investigated problems in speaking English encountered by students. Those problems are: (1) insufficient vocabulary knowledge, (2) difficulties in grammar, (3) fearing negative responses, (4) low self-esteem, and (5) anxiety when speaking English. Noprival (2016) also offered some solutions to overcome the problems. They argued that participants who are lacking of vocabulary and grammar knowledge should get more reinforcements. These reinforcements can be given by English teachers. Besides, panaceas that can be offered by the teachers are by providing various teaching methods, approaches, strategies and techniques. Also, the teacher should motivate their students to speak in English.

Seeing from previous studies, it is safe to agree that generally, people who use English as Foreign Language have various problems in speaking the language. Some solutions have been mentioned in few studies. One solution that can be proposed is designing classroom activities that to be appropriate in encouraging students to speak English fluently (Chen, 2015; Huang \& $\mathrm{Hu}, 2015$; Nazara, 2011). Appropriate classroom activities in language learning would result in high motivational students to actively engage in classroom learning environment (Lan \& Lam, 2020). Hence, examining EFL learners' insights and needs of classroom activities for teaching speaking is necessary as a basis of designing interesting classroom activities. 
In particular, EFL students' perceptions of classroom activities for teaching speaking have been studied for years by ELT professionals. Sinaga (2018) investigated 35 students' perceptions of English Day Program, an activity conducted to enhance students' speaking skills. Drawing on the data obtained from questionnaires and interviews, the study resulted in a delineation that the students were highly motivated in mastering English speaking, and they expected the English Day Program would become learning activities that assist them develop oral language skills. In a similar direction, Pratiwi and Triprihatmini (2018) examined the students' perceptions toward the use of video as teaching and learning aid in speaking classroom activities. The study revealed that the students gained good and positive perception toward the integration of video in speaking activities. Moreover, they argued that video was beneficial to identify their strengths and weaknesses in public speaking performance.

The two previous studies, however, examine EFL students' perceptions toward the predesigned teaching activities for speaking (e.g. English Day Program and the use of Video). Investigating perceptions on pre-designed teaching activities will potentially result in a positive perspective since the activities are previously well-prepared (Nugroho et al., 2020). On the other hand, the present study portrays a natural phenomenon of classroom activities for teaching speaking that have been conducted for more than half of the semester. It will provide an indepth understanding and delineation of the implementation of classroom speaking activities as an attempt to equip EFL students with adequate skills of communication. Furthermore, this study depicts EFL learners' insights and suggestions about ideal classroom activities for teaching speaking in which the literature has still been silent on. The result will contribute as inputs and references for language teachers to design appropriate speaking activities.

In the context of teaching English as a foreign language in Indonesia, designing appropriate activities is a prerequisite for an effective learning. This is the primary stage of a learning process to equip the students with good communication skills by offering them representative materials according to their needs and interests (Nugroho, 2019). To ensure the quality of teaching oral communication skills, an investigation of the implementation of teaching activities in the classroom is highly necessary. Besides, collecting and analyzing the data about the students' needs and interests will allow teachers to decide what should be done and what should not in designing the classroom activities.

According to the aforementioned explanation, the present study is carried out to fill the gap between what has been done and what needs to be done by teachers. This study aims to delineate EFL students' perceptions of the classroom speaking activities and so as to reveal the students' needs and insights for the effective teaching activities in their classroom. To ensure 
the objectives, this study is guided under the two research questions: (1) what is the students' perception of the classroom speaking activities in their classroom? and (2) what are the students' needs and insights of the activities for teaching speaking in their classroom?

\section{METHOD}

\section{Research Design}

The present study employed an explanatory mixed method design. According to Creswell (2009), the method enables the researchers to gather qualitative inputs to explain and extend quantitative results to obtain more comprehensive insight of the research. In the case of the present study, the EFL students' perceptions of speaking classroom activities were quantitatively explained by means of questionnaire, and followed by Focus Group Discussion (FGD) to gain their insights and suggestions about ideal activities for teaching speaking as the qualitative data. The ideas and views of first-year students of English department at a university in Malang were revealed by following this approach. This study further focused on the contextualization of the data which is an essential aspect of this study. Therefore, the data were interpreted only in the context of teaching administration in the university where they were gathered. This study does not concern on the generalization, but rather on the accuracy of the phenomenon being studied.

\section{Participants}

This study involved ninety-two (92) first-year students of English department at a university in Malang who were taking English for Specific Purposes program as the participants. They were amounting to $65 \%$ of the total population and this was accepted to represent the research subjects. According to Fincham (2018), 60\% of the population has met the minimum response's rates and in this research context, we have $65 \%$. Some participants (named P1-P6) were also conveniently invited for Focus Group Discussion (FGD).

\section{Data Collection}

To reach an in-depth description of the students' perceptions and their needs and insights about classroom activities for teaching speaking, a 10-item likert-scale questionnaire followed by a Focus Group Description (FGD) were administered. The questionnaire was arranged based on two primary points; the learning topics and activities in the classroom, since it attempted to examine the students' perceptions on the two points. Before being administered, the questionnaire was piloted to 25 students and revised based on inputs given by them to ensure its practicality. The data were elicited through five options which ranged from 1 "Strongly disagree", 2 "Disagree", 3 "Neutral", 4 "Agree", to 5 "Strongly agree" (Dörnyei, 2014). The 
participants were instructed to select one of the choices reflecting their thoughts and perceptions.

The administration of the questionnaire was followed by the FGD to reveal the participants needs and insights of activities for teaching speaking. Eight (8) participants were selected by using convenient sampling technique and engaged in about 90 -minute discussion. Convenient sampling helps researchers in conducting short duration and low budget research (M. Saunders et al., 2012). Also, it usually provides rich results since the participants could interact at the same time to deal with the same topic of discussion (Poedjiastutie \& Rifah, 2019).

\section{Data Analysis}

Calculating the data obtained from questionnaire and transcribing the result of FGD were the primary steps in the process of data analysis. Firstly, we calculated the likert-scale by finding out the total score per item by using the formulation $T \times P n$, in which $T$ is the total of participants' response and $P n$ is the likert score. We also decided the maximum and minimum score. The maximum score was 460, gathered from the maximal likert score (5) x number of participants (92). The minimum score was 92, obtained from the minimal likert score (1) $\mathrm{x}$ number of participants (92). After that, we found the Index (the percentage) by dividing the total score with the maximum score then was calculated into 100 . The index was then used as qualification criteria to draw the conclusion and summarized as follows: 0\%-19.99\% means "Strongly disagree”, 20\%-39.99\% means "Disagree”, 40\%-59.99\% means "Neutral”, 60\%79.99\% means “Agree”, and 80\%-100\% means "Strongly agree".

The second step was transcribing the results of FGD. After that, the researchers read the data continuously and repeatedly to earn the initial points based on the research questions. The researchers performed the same procedures until the saturation point was achieved. Saturation point is the point in the data analysis that shows no new information (Carlsen \& Glenton, 2011). It happens when the researchers revealed similar data over and over again. Saturation point is a clear indication for the researchers to continue to the next analysis (Saunders et al., 2018). The data from the initial points were then coded to identify the classification and the emerging trends. At the same time, the researchers also removed repeated and unnecessary data. The classified data were further utilized as the basis of interpretation and conclusion drawing.

\section{RESULT AND DISCUSSION}

This section delineates the findings with regard to the two research questions concerning on the students' perception toward the speaking activities in their class and their insights and needs of activities for teaching speaking. It also discusses the finding in relation to relevant 
literature. Several statements of the participant are quoted (the authors translate without changing the intention) to support the delineation of the findings.

\section{Students' Perception toward the Classroom Speaking Activities}

Table 1 describes the result of questionnaire that measure students' perception toward speaking classroom activities. The questionnaire consists of the items, participants' responses, total score, maximum score, and index. The items are in the forms of statements about process, topics, feedback and activities included in the speaking classroom. The responses available are; strongly disagree, disagree, neutral, agree and strongly agree.

Table 1. Students' perceptions toward the speaking classroom activities

\begin{tabular}{|c|c|c|c|c|c|c|c|c|}
\hline \multirow{2}{*}{ No. } & \multirow{2}{*}{ Statements } & \multicolumn{5}{|c|}{ Response } & \multirow{2}{*}{ Total } & \multirow{2}{*}{$\begin{array}{c}\text { Index } \\
(\%)\end{array}$} \\
\hline & & SD & $\mathrm{D}$ & $\mathrm{N}$ & A & SA & & \\
\hline 1 & $\begin{array}{l}\text { I like the process of } \\
\text { learning speaking in my } \\
\text { class. }\end{array}$ & 0 & 0 & 48 & 212 & 115 & 375 & 81.52 \\
\hline 2 & $\begin{array}{l}\text { The topics are relevant to } \\
\text { my need and interest. }\end{array}$ & 0 & 0 & 39 & 316 & 0 & 335 & 77.17 \\
\hline 3 & $\begin{array}{l}\text { The teaching activities } \\
\text { meet my needs in joining } \\
\text { speaking class. }\end{array}$ & 0 & 0 & 0 & 268 & 125 & 393 & 85.43 \\
\hline 4 & $\begin{array}{l}\text { Participation in the } \\
\text { activities has improved my } \\
\text { self- confidence in } \\
\text { performing speaking. }\end{array}$ & 0 & 0 & 0 & 368 & 0 & 368 & 80.00 \\
\hline 5 & $\begin{array}{l}\text { The teaching activities } \\
\text { have helped me improve } \\
\text { my fluency. }\end{array}$ & 0 & 0 & 0 & 368 & 0 & 368 & 80.00 \\
\hline 6 & $\begin{array}{l}\text { During the activities, I had } \\
\text { opportunities to improve } \\
\text { my vocabulary. }\end{array}$ & 0 & 0 & 48 & 304 & 0 & 352 & 76.52 \\
\hline 7 & $\begin{array}{l}\text { The lecturer gives me } \\
\text { feedback when making } \\
\text { mistakes. }\end{array}$ & 0 & 0 & 0 & 368 & 0 & 368 & 80.00 \\
\hline 8 & $\begin{array}{l}\text { I am actively participating } \\
\text { in the teaching activities. }\end{array}$ & 0 & 0 & 72 & 272 & 0 & 344 & 74.78 \\
\hline 9 & $\begin{array}{l}\text { The teaching activities } \\
\text { encourage me to improve } \\
\text { my speaking ability. }\end{array}$ & 0 & 0 & 0 & 356 & 15 & 371 & 80.65 \\
\hline 10 & $\begin{array}{l}\text { The teaching activities are } \\
\text { designed as real as } \\
\text { everyday communication. }\end{array}$ & 0 & 0 & 0 & 368 & 0 & 368 & 80.00 \\
\hline
\end{tabular}

Table 1 depicts that the students positively perceive the implementation of classroom speaking activities in their classroom. It is presented in the table that the average index (\%) of all questionnaire items is above $74 \%$, which means the students do agree with teaching activities conducted by their teachers during the time of observation. It also can be seen that the two 
primary points of this research, i.e. learning topics and classroom activities, are considered as good and representative by the students of English department as the participants.

As can be seen in Table 1, the item that has the highest score is item number three. The students are agree or strongly agree that the teaching activities meet students' need in joining speaking class. Item number two comes second in score. The students state that they like the process of learning speaking in their class.

Then, item number nine comes third. Most students are agree that the teaching activities encouraged them to improve their speaking abilities. The fourth, fifth, seventh and tenth items get the fourth biggest score. Students believe that their participation in the activities has improved their self-confidence in speaking. Next, the item number two comes fifth. According the students, the topics are relevant to their needs and interests. Item number six gets the score of 352. It is the sixth biggest score in sequence. This item mentions that students have opportunities to improve their vocabularies during the activities. The eighth item comes last in score. This item with the lowest score conveys that no students are strongly agree that they actively participating in the teaching activities. The students give neutral and agree responses for that statement.

According to information given in Table 1, teachers are expected to continue developing appropriate classroom activities. This is in line with a study done by Anjaniputra (2013) which states that students' gave positive attitudes towards the strategies used by the teacher in teaching speaking. The strategies implemented by the English teacher were: cooperative activities, roleplay, creative tasks, and drilling. The students responded that the activities helped them to speak.

In the context of higher education, the result of this study confirms the study reported by Pratiwi and Triprihatmini (2018) that public speaking learners of a university in Indonesia have good or positive perception toward the integration of video-based classroom activities to enhance speaking performance. However, the result of this study challenges the finding of Huang and Hu (2016) that investigates Chinese university students' perception of classroom speaking activities by comparing two groups of participants, i.e. freshman and sophomores of a university in China. Huang and $\mathrm{Hu}$ (2016) reported that students' perception of freshmen and sophomores about the speaking activities were not completely matched. The difference between the results of the present study and Huang and Hu's finding might be due to the diversity of the participant involvement, in which their study compared two groups of participants. 


\section{Students' Needs and Insights for Ideal Classroom Speaking Activities \\ The needs of English for every-day communication}

Based on the result of Focus Group Discussion, the students mentioned that oral communication is the most important skill to be acquired.

"In my opinion, the most important skill of English is oral communication (speaking) rather than other skills such as writing, reading, and listening” (P.3)

Most participants in the FGD session clearly stated that speaking skill was essential to support their performance in the every-day communication. In addition, it is going to be a verysupporting skill to develop themselves when they involve in a business environment.

"Nowadays, the most important thing to get a good job in Indonesia is the ability to communicate and negotiate. That is why, speaking skill has a great contribution to support our performance in daily life and in business environment context" (P.1)

\section{The needs of English for presentation}

There is need for speaking in order to perform a good presentation in an academic and business environment. From the FGD session, the participants stated that oral English communication was highly needed for them when they were assigned to present materials in front of the class and to perform a presentation in a working place later.

"One of the important uses of oral English communication is to perform a presentation both in academic context and in working place later when we are working. If we cannot speak English, we will not be able to deliver our materials well in the presentation. Not only that, performing a good presentation will also give special impression for our friends and colleagues and this will enhance our careers" (P.6)

\section{The needs of obtaining a good score in TOEFL and IELTS}

The participants agreed that oral English communication was necessary not only for formal presentation, but also in the day to day conversation including speaking in the TOEFL and IELTS. They argue that most of the jobs nowadays clearly require a certificate of English proficiency in which oral communication is tested there.

"English is also necessary to obtain a good score in English test such as TOEFL and IELTS. Therefore, it is a must for us to acquire English especially speaking. Most of jobs today need certificate of English proficiency" (P.2)

In addition, most of the participants also believed that when they acquired speaking skill, they would be easy to master other English skills.

\section{Maximizing technological-based learning}

The FGD session was also to reveal the insights from the participants for an effective teaching activities in a speaking classroom. One participant suggested that the speaking activities should be carried out by maximizing the use of technology. She argued that the 
twenty-first century teaching must be based on the ICT as every student now possesses gadget in hand. Therefore, English teachers are strongly suggested to create an innovative and fun activities by utilizing the technology.

"In the era of globalization like today, teaching activities should be integrated with technology including teaching oral English communication. There are some available platforms in the internet we can use to improve our speaking skill such as voxopop, Edmodo, even our social media like facebook, whatsApp, and Instagram. I am sure that will be very interesting" (P.1)

\section{More role-play activities}

Another participant in FGD stated that he was interested and felt enthusiastic when practicing speaking English through a role-play activity. He clearly argued that role-play activities could encourage him to be involved in the teaching and learning process. When the researchers asked other participants in the FGD, they absolutely agreed that role-paly activities were effective to practice oral English communication skill.

"I suggest to use role-paly activities in speaking classroom because I like that. I feel motivated to speak English and to involve in the learning activities when the teacher apples a role-play. Besides, role-play activities also give me chance and exposure to speak and speak in English. I think English teachers should apply this kind of activities in the class to improve students' speaking skills" (P.6)

\section{More games and outdoor activities}

Besides role-plays, the participants also suggested games and outdoor activities to enhance their speaking skills. They argued that practicing oral communication should be conducted in an enjoyable and joyful activities such as by utilizing games and performing in an outdoor place. Also, according to them, games are very famous for the undergraduate students nowadays. Therefore, they suggested that integrating games in teaching speaking would be an interesting learning.

"In this century where most undergraduate students have a smartphone in their hand, using games to learn and practice speaking English is highly recommended. I am sure it will be an interesting learning for students. Additionally, somehow teacher can move the class into an outdoor activity. It seems fun and pleasure." (P.5)

The finding of the FGD revealed the students' needs and insights of representative activities for teaching speaking in their class. Based on the aforementioned needs and insights, the result of this study is in consistent with what have been found by Poedjiastutie and Rifah (2019), who examined the oral communication needs of engineering students. The result of their analysis revealed some communication needs such as the needs of English as requirement for jobs, professional functions, casual conversation, and job promotion. These needs are quite 
similar in this study which reveal oral English needs of the participants for every day communication, for obtaining a good remark in TOEFL and IELTS, and for performing presentation. However, Poedjiastutie and Rifah's (2019) research slightly examines the participants' insights for activities of teaching speaking which are presented in this study.

Another response found in FGD mentioned that the use of ICT in this era is needed. Following the close relation between students and gadgets, the use of technology in classroom activities is encouraged. This idea is supported by a study done by Benmeddah (2017). She found out that the utilization of ICT are essential in teaching learning processes, especially in enriching students' speaking abilities. The use of ICT could develop students' participation during lectures.

More role-plays, games and outdoor activities were also expected by the students. They felt more motivated when speaking in role-play activities. Students also felt more comfortable in speaking while doing games and outdoor activities. The benefits of role-plays in encouraging speaking are also investigated by Fadilah (2016). The study concluded that role play was a technique that can develop students' fluency, inspires students to have interactions with other students, raises students' motivation and brings about more enjoyable teaching and learning processes.

In the light of the results above, the present study provides contributions to English language teaching, especially in speaking. First, the present study gives information on students' perceptions about the classroom activities done in their speaking class. The classroom activities are positively perceived by the students. A similar study done by Nazara (2011) also investigated students' opinions on their speaking class. The students in the study agreed that the materials and activities were varied and interesting. However, this study has not given information on students' preferences of classroom activities.

The second contribution submitted by the present study is the information on students' insights and needs on activities in the classroom. The students mentioned that they need English for daily communication, presentation and fro getting good scores in TOEFL and IELTS. Students hoped that the use of technology in the classroom can be maximized. Students also wanted to have role-plays, games and outdoors activities as parts of their speaking class.

\section{CONCLUSION}

The data analysis illustrates that the students positively perceive the implementation of speaking activities in their classroom. However, the result of FGD showed that there are some insights and needs from the students related to the ideal classroom activities for teaching speaking. The findings of this study might contribute as insights for English teachers in e-ISSN: 2089-2810 
designing representative classroom speaking activities as a prerequisite of an effective teaching. Further researchers are recommended to conduct a similar context of study with other settings and participants to check and confirm the results of this study and also to do further investigation of the students' needs and insights of activities for teaching speaking.

\section{ACKNOWLEDGEMENT}

The authors acknowledge all parties whose contribution makes the present study is successfully conducted. Thanks and honor are dedicated to the students of a university in Malang as the participants where this study was carried out.

\section{REFERENCES}

Abrar, M., Mukminin, A., Habibi, A., Asyrafi, F., \& Marzulina, L. (2018). “ If our English isn't a language, what is it?" Indonesian EFL Student Teachers' Challenges Speaking English. Qualitative Report, 23(1).

Anjaniputra, A. G. (2013). Teacher's strategies in teaching speaking to students at secondary level. Journal of English and Education, 1(2), 1-8.

Benmeddah, W. (2017). The Use of ICT in Developing the Speaking Skill in EFL Classes: Case of First Year EFL Students at the University of Tlemcen.

Carlsen, B., \& Glenton, C. (2011). What about N? A methodological study of sample-size reporting in focus group studies. BMC Medical Research Methodology, 11(1), 26.

Chen, T. H. (2015). EFL undergraduates' perceptions of blended speaking instruction. English Teaching and Learning, 39(2), 87-120. https://doi.org/10.6330/ETL.2015.39.2.04

Creswel, J. W. (2009). Research design: Qualitative, quantitative, and mixed methods approaches. Los Angeles: University of Nebraska-Lincoln.

Darmadi, H., Sudarsono, S., \& Regina, R. (2019). Using Operation Technique to Teach Speaking of Procedure Text. Jurnal Pendidikan Bahasa, 8(2), 210-231.

Dörnyei, Z. (2014). Researching complex dynamic systems:'Retrodictive qualitative modelling'in the language classroom. Language Teaching, 47(1), 80-91.

Fadilah, F. (2016). Teaching Speaking by Role-Play Activity. OKARA: Jurnal Bahasa Dan Sastra, 10(2), 209-216.

Huang, X., \& Hu, X. (2015). Teachers' and Students' Perceptions of Classroom Activities Commonly Used in English Speaking Classes. Higher Education Studies, 6(1), 87. https://doi.org/10.5539/hes.v6n1p87

Keliat, M. (2013). Pemetaan Tenaga Terampil Indonesia dan Liberalisasi Jasa ASEAN Laporan Penelitian. Jakarta: ASEAN Study Center Universitas Indonesia Bekerja Sama Dengan Kementerian Luar Negeri Republik Indonesia.

Lan, W., \& Lam, R. (2020). Exploring an efl teacher's beliefs and practices in teaching topical debates in mainland China. Iranian Journal of Language Teaching Research, 8(1), 2544 .

Nazara, S. (2011). Students' perception on EFL speaking skill development. JET (Journal of English Teaching), 1(1), 28-43.

Noprival, N. (2017). Students' Voice: EFL Speaking Problems on English Day Program at One 
Senior High School In Indonesia. Jurnal Ilmiah Universitas Batanghari Jambi, 16(1), $77-81$.

Nugroho, A. (2019). Request Realizations of Indonesian Esp Lecturers. Celtic: A Journal of Culture, English Language Teaching, Literature \& Linguistics, 6(1), 1. https://doi.org/10.22219/celticumm.vol6.no1.1-13

Nugroho, A., Zamzami, M. R. A., \& Ukhrowiyah, N. F. (2020). Language input, learning environment, and motivation of a successful EFL learner. Journal on English as a Foreign Language (JEFL), 10(1), 46-69.

Poedjiastutie, D. (2019). English Communication Needs of Engineering Students. International $\begin{array}{lllll}\text { Journal of Language and } & \text { Linguistics, } & \text { 7(2), }\end{array}$ https://doi.org/10.11648/j.ijll.20190702.13

Pratiwi, S. W., \& Triprihatmini, V. (2018). Students' Perception on the Use of Video to Assess Performances in Public Speaking Class. LLT Journal: A Journal on Language and Language Teaching, 21(Suppl), 33-42.

Renandya, W. A., Hamied, F. A., \& Nurkamto, J. (2018). English language proficiency in Indonesia: Issues and Prospects. Journal of Asia TEFL, 15(3), 618.

Saunders, B., Sim, J., Kingstone, T., Baker, S., Waterfield, J., Bartlam, B., Burroughs, H., \& Jinks, C. (2018). Saturation in qualitative research: exploring its conceptualization and operationalization. Quality \& Quantity, 52(4), 1893-1907.

Saunders, M., Lewis, P., \& Thornhill, A. (2012). Business research methods for business students. Harlow: Pearson Education Ltd.

Sinaga, O. (2018). Students' Perception on the Role of English Day Program in Speaking Skill Development. JET (Journal of English Teaching), 4(2), 103-117.

Zedeck, S., Cascio, W. F., Goldstein, I. L., \& Outtz, J. (1996). Sliding bands: An alternative to top-down selection. 